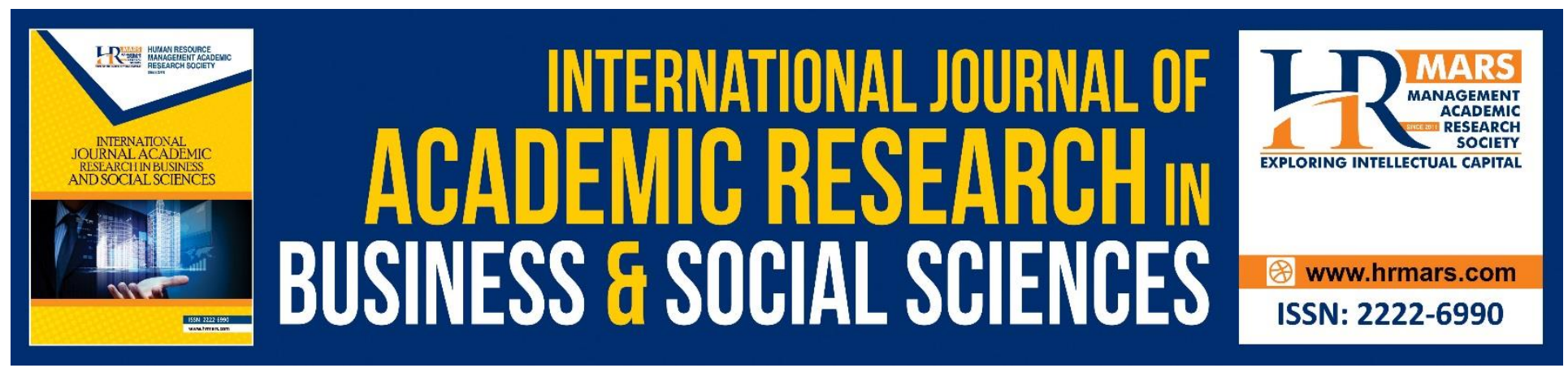

\title{
The Stakeholders Perceptions towards the Corporate Social Responsibility Reporting
}

Norfadzilah Rashid, Wan Norhayate Wan Daud, Fakhrul Anwar Zainol, Fauzilah Salleh, Ahmad Shukri Yazid, Wan Anisah Endut, Noryati Yaakub, Puspa Liza Ghazali, Asyraf Afthanorhan, Berhanundin Abdullah

To Link this Article: http://dx.doi.org/10.6007/IJARBSS/v8-i11/5171 DOI: $10.6007 /$ IJARBSS/v8-i11/5171

Received: 14 Nov 2018, Revised: 13 Dec 2018, Accepted: 15 Dec 2018

Published Online: 16 Dec 2018

In-Text Citation: (Rashid et al., 2018)

To Cite this Article: Rashid, N., Daud, W. N. W., Zainol, F. A., Salleh, F., Yazid, A. S., Endut, W. A., ... Abdullah, B. (2018). The Stakeholders Perceptions towards the Corporate Social Responsibility Reporting. International Journal of Academic Research in Business and Social Sciences, 8(11), 1303-1310.

\section{Copyright: (C) 2018 The Author(s)}

Published by Human Resource Management Academic Research Society (www.hrmars.com)

This article is published under the Creative Commons Attribution (CC BY 4.0) license. Anyone may reproduce, distribute, translate and create derivative works of this article (for both commercial and non-commercial purposes), subject to full attribution to the original publication and authors. The full terms of this license may be seen

at: http://creativecommons.org/licences/by/4.0/legalcode

Vol. 8, No. 11, 2018, Pg. 1303 - 1310

Full Terms \& Conditions of access and use can be found at http://hrmars.com/index.php/pages/detail/publication-ethics 


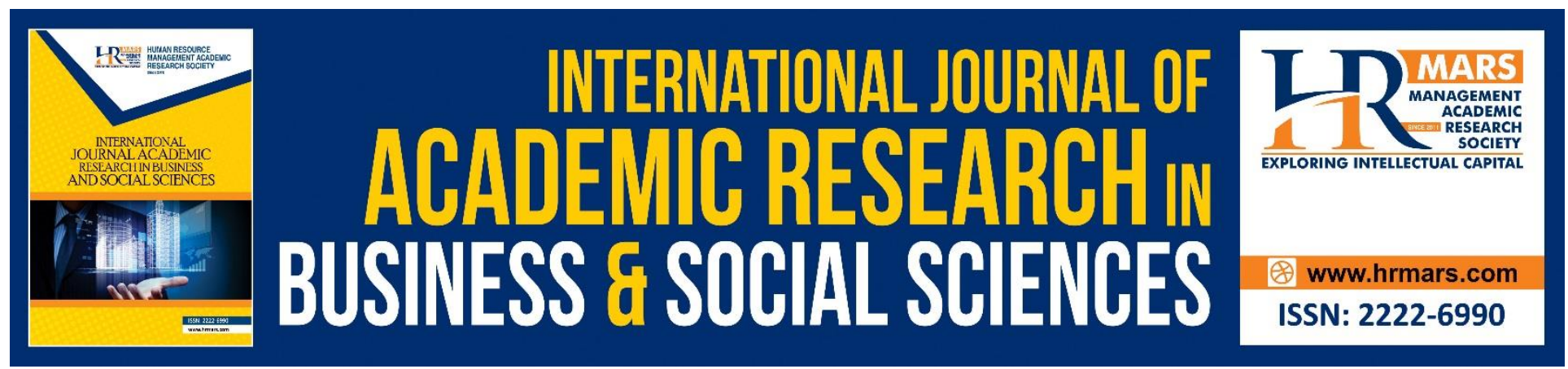

\title{
The Stakeholders Perceptions towards the Corporate Social Responsibility Reporting
}

\section{${ }^{1}$ Norfadzilah Rashid, ${ }^{2}$ Wan Norhayate Wan Daud, ${ }^{3}$ Fakhrul Anwar Zainol, ${ }^{4}$ Fauzilah Salleh, ${ }^{5}$ Ahmad Shukri Yazid, ${ }^{6}$ Wan Anisah Endut, ${ }^{7}$ Noryati Yaakub, ${ }^{8}$ Puspa Liza Ghazali, ${ }^{9}$ Asyraf Afthanorhan, ${ }^{10}$ Berhanundin Abdullah}

$1,2,3,4,5,6,7,8,9$ Faculty of Economics and Management Sciences, Universiti Sultan Zainal Abidin, Gong Badak Campus, 21300 Kuala Nerus, Terengganu, Malaysia

${ }^{10}$ Faculty of Islamic Contemporary Studies, Universiti Sultan Zainal Abidin, Gong Badak Campus, 21300 Kuala Nerus, Terengganu, Malaysia

\begin{abstract}
A study on Corporate Social Responsibility has growing rapidly in the corporate world and become part of the business. Many organization introduced Corporate Social Responsibility into their business activities and encourage communication through many types of channel on their Corporate Social Responsibility activities to stakeholder. In this era, an organization will face high expectation from the stakeholder group that showing they are expecting more from the organization. An organization become an attention because of the pressure on social and environmental problem. Its lead to the preparing the Corporate Social Responsibility report which is the preparation of a sustainability report that will become one of the challenging part for the company concern. The preparer will need to analyse based on his common sense in providing diverse framework and guidelines. A lack of unity and accurate legal regulation can be noticed in this era causes companies incurred on various but so far the companies applied the guidelines when it is the time to report on Corporate Social Responsibility. Some companies will prepare a separate sustainability show that the separate sustainability report will only contain information and business that related to economy, ecology and social sustainability. The concept of sustainability become a new challenge to the companies because taking a consideration on ecological and social aspect that is not become a focus on company day to day management. It's depending on the reporting type, structure and the level of knowledge which the viewer of those information with regard to the perception of Corporate Social Responsibility or Sustainability reporting is hard to investigate. This research is to encourage awareness for preparer and also the stakeholder that the choice might be different be different
\end{abstract}


INTERNATIONAL JOURNAL OF ACADEMIC RESEARCH IN BUSINESS AND SOCIAL SCIENCES

Vol. 8, No. 11, Nov, 2018, E-ISSN: 2222-6990 @ 2018 HRMARS

depends on what type of report it is. As a way to determine the different in perception, an eyetracking technology is applied. The contribution of Eyes-tracking will determine the different sustainability report types from a stakeholder perspective.

\section{BACKGROUND}

Corporate social responsibility reporting is a method of a companies to combine Corporate Social Responsibility and sustainability into a decision making process. Corporate Social Responsibility will help the companies to identified risk and opportunities that exist the world of business. By having this report, company will be able to engage with the stakeholder to know where actually the direction of the business. Corporate Social Responsibility were able to build a good reputation or image of a company.

A good Corporate Social Responsibility report that are relevant and useful will increase the quality of being trust by stakeholder and also the public. In return, the company will gain a competitive advantage and also will improve the employee morale and motivation to gain a confident to perform their job within the company. Corporate Social Responsibility reporting are useful to the internal user and external user. Internal user refer to the company management and employees within the company that use financial information for making decision and next managing the business. For external user, they are an entities who do not involve in running the business but interested in performance of the company.

Based on the article, this corporate social responsibility are important to both user because ability to directly know and ability to measure are necessary for the basis of respective strategies and aims. They must understand how the sustainability three pillar mode start from the ecology which is preservation of environment and nature for future. It's also include economy which is assurance of lasting prosperity that lead to the careful of using the available resource. Lastly, social aspect which is the future oriented development of society.

\section{LITERATURE REVIEW}

Corporate social responsibility (CSR) concept is now change to a new integrated design known as corporate sustainability and responsibility. CSR is defined as "the continuous dedication by business to act morally and grant to economic improvement while make a better life for the employees and their household who is also the citizen and society". Besides, Australian government had defined the corporate sustainability as "hold within strategies and applications that have purpose to fulfil the stakeholders need today and at the same time secure, support and intensify all resources that are essential in the future (Pirnea, Olaru, \& Moisa, 2011). CSR is more towards the non-financial activities but corporate sustainability focus on the effect of environmental factors that will give impacts to the environment.

Companies concerned nowadays are the way on how to prepare a sustainability report in order to tell the stakeholders about what they want to be informed. Sustainability report is demanded by the stakeholders to increase the transparency and accountability, increase corporate reputation and brand value, legitimation of corporate activities; comparison and benchmarking against competitors; signalling competitiveness; establishing and supporting employee motivation and supporting corporate internal information and control processes (Konuk, 2017). 
Stakeholders are groups of people that have relationship with the company such as creditors, directors, employees, suppliers, union and government (Konuk, 2017) . Stakeholder's perspective need to be considered in the process of preparing that report.

Stakeholder theory is one of the theories that can explain why companies disclose information sustainability. This is because the companies have to maintain their relationship with the stakeholders in order to survive for a long term in business. Stakeholders pursue different economic, environmental and social interest, that determines the success of an organization (Konuk, 2017). However, it is impossible for the companies to meet all of the stakeholder's interest equally. According to (Konuk, 2017), the companies will give more importance to more powerful stakeholders. Therefore, the information that will be disclosed in the reports will be based on the needs of those stakeholders. If $a$ is responsive to the needs of its stakeholders, the developed good relationships provide a competitive advantage for the company (Fontaine, 2006).

\section{METHODOLOGY}

Methodology is a system of broad principles or rules from which specific methods or procedure may be derived to interpret or solve different problems within the scope of a particular discipline. A methodology is not a formula but a set of practice.

In the research paper Corporate Social Responsibility Reporting - a Stakeholder's Perspective Approach produce by Thorsten Litfin, Gunther Meeh-Bunse, Katja Luer, Ozlem Teckert, it is stated that methodology used in collecting the information is using the eye-tracking approach combine with conventional approach; opinion survey. Using the equipment "Tobii Pro Glasses 2" eye-tracking approach is a modern and latest method that is used by researchers to study human behaviour by showing exactly what a person is looking at in real time as they move freely in any real-world setting. Understand how people interact with their environment, what catches their attention, drives their behaviour, and influences decision making. Wearable and mobile eye tracking system opens up entirely new opportunities for behavioural studies. It is an equipment with the latest technology to study human behaviour and also can be used to collect data or information.

This modern approach is combine with conventional method in gathering information, opinion survey where the researchers meet the subject or participant face-to-face and asking question. It is more reliable and convincing for the information if it is acquire directly from the subject.

The participant or subject of this study were 12 business students specialized in financial accounting. These students are required to answer some questions that is related to the real world situation of corporate social responsibility reporting. The question is about what did the real stakeholder want to know about the CSR and the students are required to answer it. Different types of CSR reporting were being used which are; 1) an embedded report 2) a separate report and 3) reference report and all of the report have been given to the students one week before the information collecting process.

The reason of why different type of reporting were used is to determine whether it could influence the search behaviour of stakeholder and also to determine the type of reporting that 
INTERNATIONAL JOURNAL OF ACADEMIC RESEARCH IN BUSINESS AND SOCIAL SCIENCES Vol. 8, No. 11, Nov, 2018, E-ISSN: 2222-6990 @ 2018 HRMARS

help the stakeholder in searching for information the most. Those 12 students were evenly assigned to those three different reporting types (Litfin et al., 2017).

\section{DISCUSSION}

The methodology that is being used in the study Corporate Social Responsibility Reporting - a Stakeholder's Perspective Approach is very practical. The researchers have used a very modern type approach in getting the information which is the eye- tracking approach that used certain equipment and combining with the conventional approach in getting information which is by using opinion survey (face-to face). We all know face-to-face with the subject will get a much more reliable information. Regardless of how practical and reliable the methodology that is being used, there are some flaws in the study. The study neglects another important element that makes this study less convincing regarding of their results.

The research paper neglects the important elements that makes the ending result more convincing; types of subject that is being used in getting the information and also the number of participants or subject of the study. The researchers did not take into consideration the types or level of understanding of participants towards the real world situation. The study stated that in achieving the end results, they did not approach the real stakeholder in getting the information but instead they approach the students to achieve the end result. This is very irrelevant because students are hardly involved in corporate-level business and they did not have the necessary knowledge in interpreting the corporate social responsibility reporting. Because of the lack of knowledge, some of the participant (students) could not even answer even the simple question that was prepared for them. The time that is given for the information gathering process were also increased from 10 minutes to 20 minutes.

Besides the aspect of knowledge of the participants, there is also irrelevancy regarding the sample size (participants). The study only involves a very small numbers of participants, which are 12 numbers of students. The credibility of the end result was being tainted by fact that only small sample size is being used (which is not even close to compare with the situation of the real world), not to mention that the study also use unknowledgeable subject in gathering the information to get the end result. Additionally, the participants (students) did not represent the real stakeholder that involve in giving the opinion towards corporate firm activities.

\section{Impact of Good Corporate Social Responsibility}

Without a doubt that a good CSR reporting could improve business performance. If the companies really to deliver a good sustainability report to their stakeholder, they will receive many benefits. Their customers will believe more towards the company, more people will recognized their brand, their employees will improve in workforce and a good relationship with society.

A good Corporate Social Responsibility reporting will affect many parties. It will make all of the stakeholders easier to find what they want to know and also they will believe more towards the company because with good CSR reporting, the stakeholder assume that the company did not have anything to hide. 
Shareholders are the owners of the organization, and for this reason their claim on organizational resources is usually considered superior to the claims of other stakeholders. They contribute to the organization by investing money in the organization through the purchasing of company shares or stock (Konlaan and Hanson, 2008). With good CSR reporting many people will contribute money and become the shareholder of company.

Managers are the employees of an organization who are assigned the role of managing the organization's resources and making sure that the organizations set goals and targets are successfully met. This is achieved through the contribution of their skills to direct and respond to pressures from different parts of the organization (Konlaan and Hanson, 2008). Their workforce and performance will increase with good CSR. Other stakeholders are customers. They are known to be the largest stakeholder group outside an organization. Customers have the choice of selecting from alternative products by their judgment of what they are getting in relation to their money's worth. The money paid for the product is their contribution to the organization and this goes to reflect the value they feel they receive from the organization (Konlaan and Hanson, 2008). Company reputation increasing through good CSR reporting is what attract the people to be their customer.

\section{CONCLUSION}

The study of this paper indicates that Corporate Social Responsibility report has become the most require thing in the corporate reputation. Research indicates that an organizations of all types and sizes may show a good corporate reputation by having a good Corporate Social Responsibility report.

As a result, combining eye-tracking and survey approach are important to the analysis of search and information for all type of sustainability report. Nowadays, it's very crucial for the business to having exercised on the sustainability of the report. There are several reason why an organization are engaging the Corporate Social Responsibility report. It's because an organizations may engage in Corporate Social Responsibility report because of the sustainability for all the type of report it's very important to stakeholder so that they can evaluate how well the business operate. No matter for what reasons organizations invest in Corporate Social Responsibility report, all the reasons will lead to better corporate reputation. As a result, organizations shouldn't treat Corporate Social Responsibility as opportunity that is not necessary for the business.

There is a limitation that an organization will faced but subsequent study should be try to overcome these limitation. Literature analysis showed that organizations should pay attention on the stakeholder theory. On the other hand, Corporate Social Responsibility report must be effectively communicated through advertising, annual reports or stakeholder dialogue. It has been decided that a key of corporate reputation is stakeholder groups' perceptions of organization's on Corporate Social Responsibility report as Corporate Social Responsibility and corporate reputation are positively correlated. If stakeholder groups become aware of sustainability Corporate Social Responsibility report, they will assure that the organization will maintain or improve its corporate reputation. 
However, it should be noted that the sustainability of Corporate Social Responsibility report is an ideal result what will permit a direct conclusion about type of report it is to be applied in the enterprise. It's mean that the perception of those information need to be examine on what actually the potential stakeholder can remember from the provided information on a specific time.

\section{RECOMMENDATIONS}

As sustainability reporting has become more regular among the corporations to be part of the organization's corporate social responsibility platforms, a new set of terms and concepts were formed and worked out to become more comprehensive. To do this, an integrated report had been constructed to replace the existing sustainability report. This was created with the objective of analysing and sharing both sustainability and financial performance within the same documents.

The Global Reporting Initiative or GRI had widely been used as a standardized reporting framework in preparing the sustainability report. It has conducted a study on the integrated report by focusing on rising issues and was shared to public. This transition are been closely monitor by the International Integrated Reporting Council (IIRC) as they seek to facilitate the companies by building a framework that are doable to apply in their report. They had released a Consultation Draft and currently soliciting the feedback that runs on a certain period.

The framework has highlighted several important components such value creation over different time period as well as capital allocation. This is fundamental as it will affect the company's business model, growth strategy and its ability to participate successfully in the integrated reporting process.

In order enhance the proficiency of this integrated reporting, the IIRC has request every corporation to read and evaluate the framework and provide any general commentary. This is still an on-going effort as the style and demand towards the reporting standard changes based on the market environment.

\section{REFERENCES}

Konlaan, B. Y. and Hanson, P. K. (2008) 'The Impact of Corporate Social Responsibility on an Organization's Stakeholders, Case Study: DHL, Sweden', School of Sustainable Development of Society and Technology, (November). Available at: http://mdh.divaportal.org/smash/get/diva2:114139/FULLTEXT01.pdf.

Fontaine, C. (2006). The Stakeholder Theory. Management, 1(December), 37-44. https://doi.org/10.1057/9780230524224

Konuk, V. (2017). Stakeholder representation in sustainability reports, (January), 1-27.

Pirnea, I. C., Olaru, M., \& Moisa, C. (2011). Relationship between corporate social responsibility and social sustainability. Economy Transdisciplinarity Cognition, 14(1), 36- 43. 
INTERNATIONAL JOURNAL OF ACADEMIC RESEARCH IN BUSINESS AND SOCIAL SCIENCES Vol. 8, No. 11, Nov, 2018, E-ISSN: 2222-6990 @ 2018 HRMARS

Integrated Reporting - A New Sustainability Reporting Standard is Taking Shape. (n.d.). Retrieved April 28, 2018, from http://www.pgsadvisors.com 